Jurnal Media Keperawatan: Politeknik Kesehatan Makassar

Vol. 09. No.02. 2018

e-issn : 2622-0148, p-issn : 2087-0035

\title{
PENGARUH SENAM DIABETES TERHADAP PENURUNAN KADAR GULA DARAH PADA PENDERITA DIABETES MELLITUS TIPE 2 DI PUSKESMAS ANTARA KOTA MAKASSAR
}

\author{
Include Of Diabetic On Desrease Blood Sugar Content To Diabetic Mellitus Patients Type II In The Center Antara \\ Makassar City \\ Hamsiah Hamzah'1, Sukriyadi², Sitti Rahmatia ${ }^{3}$, Hildawati ${ }^{4}$ \\ Poltekkes Kemenkes Makassar \\ hhildawati1@gmail.com \\ $\underline{085240597946}$
}

\begin{abstract}
ABSTRACK
Abstrack: Diabetes mellitus is a chronic condition characterized by an increase in blood glucose concentrations accompanied by the emergence of typical main symptoms, namely urine that taste sweet in large numbers. The purpose of this research is the influence of diabetes mellitus gymnastics on the decrease of blood sugar level of type 2 diabetes mellitus. This research method is kind of quantitative research by using quasi experimental research design that is experiment which have not or do not have actual experiment stimulation characteristic, because the variables which should be controlled and manipulated is difficult to find. The research design used was the One Group pretest posttest design. The sampling technique used in this research is accidental sampling technique. Accidental sampling is accidental sampling by taking cases or respondents who happen to exist or available somewhere in accordance with the research context. The sample of this research was 10 respondents. The result of the research was the influence of diabetes gymnastics on blood sugar level in type 2 diabetics at Puskesmas Antara Makassar City on the first week (Day I $p=$ 0,014), (Day II $p=0,007)$, (Day III $p=0.035)$. There is influence of diabetes gymnastics on blood sugar level in patient of type 2 diabetes at Puskesmas Antara Kota Makassar on week II (Day I $p=0,003)$, (Day II $p=0,007$ ), (Day III $p=0,020$ ). The average conclusion is the effect of diabetes gymnastics on blood sugar level in people with diabetes mellitus type 2 at Puskesmas Antara Makassar City. Suggestion In this research can give input to institution of Puskesmas Antara Makassar City can lower blood sugar level so if always give procedure and understanding of diabetes gymnastic everyday for diabetics so that patient able to do well with effect can help cure illness.
\end{abstract}

Keywords: Gymnastics, Diabetes Mellitus, Blood Sugar Level

\begin{abstract}
ABSTRAK
Abstrak: Diabetes mellitus merupakan kondisi kronis yang ditandai dengan peningkatan konsentrasi glukosa darah disertai munculnya gejala utama yang khas, yakni urin yang berasa manis dalam jumlah yang besar. Tujuan penelitian ini pengaruh senam diabetes mellitus terhadap penurunan kadar gula darah penderita diabetes mellitus tipe 2 . Metode Penelitian ini merupakan jenis penelitian kuantitatif dengan menggunakan desain penelitian quasi eksperimen yaitu eksperimen yang belum atau tidak memiliki ciri-ciri rangsangan eksperimen yang sebenarnya, dikarenakan variabelvariabel yang seharusnya dikontrol dan dimanipulasi sulit di temukan. Rancangan penelitian yang digunakan adalah rancangan One Group pretest posttest. Teknik sampling yang digunakan pada penelitian ini adalah teknik accidental sampling. Accidental sampling yaitu pengambilan sampel secara aksidental (accidental) dengan mengambil kasus atau responden yang kebetulan ada atau tersedia disuatu tempat sesuai dengan konteks penelitian. Sampel dalam penelitian ini sebanyak 10 responden. Hasil penelitiannya ada pengaruh senam diabetes terhadap kadar gula darah pada penderita diabetes tipe 2 di Puskesmas Antara Kota Makassar pada minggu I (Hari I $p=0,014$ ), (Hari II $p=0,007$ ), (Hari III $p=0,035$ ). Ada pengaruh senam diabetes terhadap kadar gula darah pada penderita diabetes tipe 2 di Puskesmas Antara Kota Makassar pada minggu II (Hari I $p=0,003$ ), (Hari II $p=0,007$ ), (Hari III $p=0,020$ ). Kesimpulan rata-rata ada pengaruh senam diabetes terhadap kadar gula darah pada penderita diabetes melitus tipe 2 di Puskesmas Antara Kota Makassar. Saran Dalam penelitian ini dapat memberikan masukan kepada institusi Puskesmas Antara Kota Makassar dapat menurunkan kadar gula darah agar sekiranya selalu memberikan prosedur serta pemahaman senam diabetes setiap hari untuk penderita diabetes sehingga pasien mampu melakukannya dengan baik yang efeknya dapat membantu penyembuhkan penyakitnya.
\end{abstract}

Kata Kunci : Senam, Diabetes Melitus, Kadar Gula Darah 
Vol. 09. No.02. 2018

e-issn : 2622-0148, p-issn : 2087-0035

\section{PENDAHULUAN}

Diabetes mellitus merupakan salah satu penyakit yang dapat diturunkan pada saat ini dengan angka kejadian yang paling banyak terjadi selain penyakit jantung dan stroke, (PERKENI,2011) dalam (Nugraha, Kusnadi, \& Subagja, 2016). Senam merupakan salah satu cara yang berperan utama dalam pengaturan kadar gula darah dan faktor resiko penyakit kardiovaskular dihambat/diperbaiki (Damayanti, 2015).

Senam diabetes adalah senam fisik yang dirancang menurut usia dan status fisik dan merupakan bagian dari pengobatan diabetes mellitus (Persadia,2000) dalam (Nuari, 2017)

Senam diabetes adalah latihan fisik aerobic bagi penderita diabetes mellitus dengan serangkaian gerakan yang dipilih secara sengaja dengan cara mengikuti irama music sehingga melahirkan ketentuan ritmis, kontinuitas dan durasi tertentu untukmencapai tujuan tertentu. Senam diabetes akan lebih baikdilakukan dalam waktu 45 menitdengan frekuensi 3-5 kali perminggu (Ashadi,2008) dalam (Nugraha, Kusnadi, \& Subagja, 2016).

Seiring dengan perkembangan zaman, pola penyakit yang diderita telah bergeser dari penyakit infeksi dan kekurangan gizi kearah penyakit degeratif yang salah satunya adalah diabetes mellitus. Menurut Kementerian kesehatan Republik Indonesia (KEMENKES RI) tahun 2014 Estimasi terakhir International Diabetes Federation (IDF), terdapat 384 juta orang yang hidup dengan diabetes mellitus di dunia pada tahun 2013 (Salindeho, Mulyadi, \& Rottie, 2016).

Tingginya angka kejadian ini menjadikan Indonesia sebagai negara penderita diabetes ke tujuh di dunia. Menurut RISKESDAS (2013) prevalensi diabetes mellitus di Indonesia mengalami peningkatan dari $1,1 \%$ di tahun 2007 meningkat meningkat menjadi 2,1\% ditahun 2013 dari keseluruhan penduduk 250 juta jiwa.

Menurut hasil Riset Kesehatan Dasar (RISDESDAS, 2013) prevalensi diabetes melltus di Sulawesi Selatan yang didiagnosis dokter sebesar
1,66 persen dan 0,5 persen. Diabetes Mellitus yang didiagnosis dokter atau berdasarkan gejala sebesar 3,4 persen. Prevalensi diabetes yang didiagnosis dokter tertinggi terdapat di Kabupaten Pinrang(2,8\%), Kota Makassar (2,5\%), Kabupaten Toraja Utara $(2,3 \%)$, dan Kota Palopo $(2,1 \%)$. Prevalensi diabetes yang didiagnosis dokter berdasarkan gejala, tertinggi di Kabupaten Tana Toraja $(6,1 \%)$, Kota Makassar $(5,3 \%)$, Kabupaten Luwu (5,2\%), dan Kabupaten Luwu Utara (4,0\%).

Hasil penelitian Witriyani (2016) mengatakan bahwa diabetes mellitus dampak yang sangat berbahaya karena dapat menibulkan komplikasi. Oleh karena itu, diperlukan usaha pengendalian yang harus dilakukan oleh penderita diabetes mellitus dalam mengendalikan diabetes mellitus yang diperlukan empat pilar penyangga yang mendukung, yaitu edukasi, diet, obat dan olahraga. Banyak penderita diabetes mellitus yang lebih focus dan hanya mengutamakan pada penanganan diet, dam mengkomsumsi obatobatan. Namun penanganan diet yang benar belum menjamin akan terkontrolnya kadar gula darah, akan tetapi hal harus diseimbangi dengan latihan fisik yang sesuai. Aktifitas atau pergerakan tubuh sering diabaikan oleh setiap penderita diabetes mellitus, hal ini dapat disebabkan oleh berbagai faktor seperti keterbatasan waktu yang melakukan olahraga karena pekerjaan, usia yang tidak memungkinkan, dan minat yang kurang untuk melakukan aktifitas, serta kurangnya pengetahuan akan pentingnya olahraga. Salah satu upaya olahraga yang bisa dilakukan pada penderita diabetes mellitus adalah senam diabetes mellitus, senam ini juga bermanfaat dalam menbantu kerja insulin karena gula dalam darah akan dialirkan sel otot kemudian di ubah menjadi energi bagi tubuh sehingga menyebabkan kadar gula darah tubuh menurun. Selain itu untuk membakar kalori yang berlebih di dalam tubuh yang mampu untuk mengontrol kadar gula darah. Alasan mengapa senam dapat mengontrol kadar gula darah adalah karena saat berolahraga, sel-sel pada otot akan bekerja keras sehingga tentunya akan lebih membutuhkan kadar gula darah dan oksigen 
dibakar menjadi energi. Berdasarkan hal tersebut, maka peneliti ingin melakukan penelitian tentang "Pengaruh Senam Diabetes Mellitus Terhadap Penurunan Kadar Gula Darah Di Puskesmas Antara Kota Makassar."

\section{PENDAHULUAN}

Diabetes mellitus merupakan salah satu penyakit yang dapat diturunkan pada saat ini dengan angka kejadian yang paling banyak terjadi selain penyakit jantung dan stroke, (PERKENI,2011) dalam (Nugraha, Kusnadi, \& Subagja, 2016). Senam merupakan salah satu cara yang berperan utama dalam pengaturan kadar gula darah dan faktor resiko penyakit kardiovaskular dihambat/diperbaiki (Damayanti, 2015).

Senam diabetes adalah senam fisik yang dirancang menurut usia dan status fisik dan merupakan bagian dari pengobatan diabetes mellitus (Persadia,2000) dalam (Nuari, 2017)

Senam diabetes adalah latihan fisik aerobic bagi penderita diabetes mellitus dengan serangkaian gerakan yang dipilih secara sengaja dengan cara mengikuti irama music sehingga melahirkan ketentuan ritmis, kontinuitas dan durasi tertentu untukmencapai tujuan tertentu. Senam diabetes akan lebih baikdilakukan dalam waktu 45 menitdengan frekuensi 3-5 kali perminggu (Ashadi,2008) dalam (Nugraha, Kusnadi, \& Subagja, 2016).

Seiring dengan perkembangan zaman, pola penyakit yang diderita telah bergeser dari penyakit infeksi dan kekurangan gizi kearah penyakit degeratif yang salah satunya adalah diabetes mellitus. Menurut Kementerian kesehatan Republik Indonesia (KEMENKES RI) tahun 2014 Estimasi terakhir International Diabetes Federation (IDF), terdapat 384 juta orang yang hidup dengan diabetes mellitus di dunia pada tahun 2013 (Salindeho, Mulyadi, \& Rottie, 2016).

Tingginya angka kejadian ini menjadikan Indonesia sebagai negara penderita diabetes ke tujuh di dunia. Menurut RISKESDAS (2013) prevalensi diabetes mellitus di Indonesia mengalami peningkatan dari 1,1\% di tahun 2007 meningkat meningkat menjadi 2,1\% ditahun 2013 dari keseluruhan penduduk 250 juta jiwa.

Menurut hasil Riset Kesehatan Dasar (RISDESDAS, 2013) prevalensi diabetes melltus di Sulawesi Selatan yang didiagnosis dokter sebesar 1,66 persen dan 0,5 persen. Diabetes Mellitus yang didiagnosis dokter atau berdasarkan gejala sebesar 3,4 persen. Prevalensi diabetes yang didiagnosis dokter tertinggi terdapat di Kabupaten Pinrang(2,8\%), Kota Makassar (2,5\%), Kabupaten Toraja Utara $(2,3 \%)$, dan Kota Palopo $(2,1 \%)$. Prevalensi diabetes yang didiagnosis dokter berdasarkan gejala, tertinggi di Kabupaten Tana Toraja $(6,1 \%)$, Kota Makassar $(5,3 \%)$, Kabupaten Luwu (5,2\%),dan Kabupaten Luwu Utara (4,0\%).

Hasil penelitian Witriyani (2016) mengatakan bahwa diabetes mellitus dampak yang sangat berbahaya karena dapat menibulkan komplikasi. Oleh karena itu, diperlukan usaha pengendalian yang harus dilakukan oleh penderita diabetes mellitus dalam mengendalikan diabetes mellitus yang diperlukan empat pilar penyangga yang mendukung, yaitu edukasi, diet, obat dan olahraga. Banyak penderita diabetes mellitus yang lebih focus dan hanya mengutamakan pada penanganan diet, dam mengkomsumsi obatobatan. Namun penanganan diet yang benar belum menjamin akan terkontrolnya kadar gula darah, akan tetapi hal harus diseimbangi dengan latihan fisik yang sesuai. Aktifitas atau pergerakan tubuh sering diabaikan oleh setiap penderita diabetes mellitus, hal ini dapat disebabkan oleh berbagai faktor seperti keterbatasan waktu yang melakukan olahraga karena pekerjaan, usia yang tidak memungkinkan, dan minat yang kurang untuk melakukan aktifitas, serta kurangnya pengetahuan akan pentingnya olahraga. Salah satu upaya olahraga yang bisa dilakukan pada penderita diabetes mellitus adalah senam diabetes mellitus, senam ini juga bermanfaat dalam menbantu kerja insulin karena gula dalam darah akan dialirkan sel otot kemudian di ubah menjadi energi bagi tubuh sehingga menyebabkan kadar gula darah tubuh menurun. Selain itu untuk membakar kalori yang berlebih di dalam tubuh yang mampu untuk 
Vol. 09. No.02. 2018

e-issn : 2622-0148, p-issn : 2087-0035

mengontrol kadar gula darah. Alasan mengapa senam dapat mengontrol kadar gula darah adalah karena saat berolahraga, sel-sel pada otot akan bekerja keras sehingga tentunya akan lebih membutuhkan kadar gula darah dan oksigen dibakar menjadi energi. Berdasarkan hal tersebut, maka peneliti ingin melakukan penelitian tentang "Pengaruh Senam Diabetes Mellitus Terhadap Penurunan Kadar Gula Darah Di Puskesmas Antara Kota Makassar.

\section{METODE PENELITIAN}

Penelitian ini merupakan jenis penelitian kuantitatif dengan menggunakan desain penelitian quasi eksperimen, Rancangan penelitian yang digunakan adalah rancangan One Group pretest posttest only design. Jumlah sampel dalam penelitian ini sebanyak 10 orang. senam di lakukan untuk setiap responden yaitu 3 kali dalam seminggu dan dilakukan 2 minggu. Analisis bivariat dengan menggunakan metode paired sample $T$ test, Wilcoxon).

\section{HASIL DAN PEMBAHASAN}

a. Umur

Tabel 1

Distribusi Frekuensi Responden Menurut Umur Sumber : Data Primer 2018

\begin{tabular}{lll}
\hline Umur & $\mathrm{N}$ & $\%$ \\
\hline 20-30 tahun & 0 & 0,0 \\
31-40 tahun & 1 & 10,0 \\
41-50 tahun & 6 & 60,0 \\
51-60 tahun & 3 & 30,0 \\
\hline Total & 10 & 100,0 \\
\hline
\end{tabular}

Dari tabel 1 diatas menunjukkan bahwa dari 10 jumlah responden terdapat $0(0,0 \%)$ responden yang umur 20-30 tahun, dan sebanyak $6(60,0 \%)$ responden yang umur 41-50 tahun yang paling banyak b. Jenis Kelamin

Tabel 2

Distribusi Frekuensi Responden Menurut Jenis Kelamin

\begin{tabular}{lll}
\hline Jenis Kelamin & $\mathrm{N}$ & $\%$ \\
\hline Laki-laki & 0 & 0,0 \\
Perempuan & 10 & 100,0 \\
\hline Total & 10 & 100,0 \\
\hline
\end{tabular}

Sumber : Data Primer 2018

Dari tabel 2 diatas menunjukkan bahwa dari 10 jumlah responden terdapat $0(0,0 \%)$ responden yang jenis kelamin laki-laki, dan sebanyak 10 $(100,0 \%)$ responden yang jenis kelamin perempuan.

c. Pekerjaan

Tabel 3

Distribusi Frekuensi Responden Menurut Pekerjaan Sumber : Data Primer 2018

\begin{tabular}{lll}
\hline Pekerjaan & N & $\%$ \\
\hline PNS & 1 & 10,0 \\
Wiraswasta & 1 & 10,0 \\
Pensiunan & 2 & 20,0 \\
lbu Rumah Tangga (IRT) & 6 & 60,0 \\
\hline Total & 10 & 100,0 \\
\hline
\end{tabular}

Dari tabel 3 diatas menunjukkan bahwa dari 10 jumlah responden terdapat $1(5,0 \%)$ responden yang pekerjaan PNS dan Wiraswasta yang paling sedikit, dan sebanyak $6(60,0 \%)$ responden yang pekerjaan Ibu Rumah Tangga (IRT) yang paling banyak

1. Analisis Univariat

a. Minggu I

Tabel 4

Distribusi Frekuensi Responden Menurut Kadar Gula Darah Sebelum Senam (Pre) Hari I

\begin{tabular}{lll}
\hline Kadar Gula Darah & $\mathrm{N}$ & $\%$ \\
\hline $100-200 \mathrm{mg} / \mathrm{dL}$ & 3 & 30,0 \\
$201-300 \mathrm{mg} / \mathrm{dL}$ & 5 & 50,0 \\
$301-400 \mathrm{mg} / \mathrm{dL}$ & 2 & 20,0 \\
\hline Total & 10 & 100,0 \\
\hline
\end{tabular}


Jurnal Media Keperawatan: Politeknik Kesehatan Makassar

Vol. 09. No.02. 2018

e-issn : 2622-0148, p-issn : 2087-0035

Sumber : Data Primer 2018

Dari tabel 4 diatas menunjukkan bahwa dari 10 jumlah responden terdapat $3(30,0 \%)$ responden yang kadar gula darah 100-200 mg/dL, sebanyak 5 $(50,0 \%)$ responden yang kadar gula darah 201-300 $\mathrm{mg} / \mathrm{dL}$, dan sebanyak $2(20,0 \%)$ responden yang kadar gula darah $301-400 \mathrm{mg} / \mathrm{dL}$.

Tabel 5

Distribusi Frekuensi Responden Menurut Kadar Gula Darah Sesudah Senam (Post) Hari I

\begin{tabular}{ccc}
\hline Kadar Gula Darah & $\mathrm{N}$ & $\%$ \\
\hline Menurun & 10 & 100,0 \\
Tidak Menurun & 0 & 0,0 \\
\hline Total & 10 & 100,0 \\
\hline Sumber : Data Primer 2018 & &
\end{tabular}

Dari tabel 5 diatas menunjukkan bahwa dari 10 jumlah responden terdapat $10 \quad(100,0 \%)$ responden yang kadar gula darah menurun, dan sebanyak $0(0,0 \%)$ responden yang kadar gula darah tidak menurun.

Tabel 6

Distribusi Frekuensi Responden Menurut Kadar Gula Darah Sebelum dan sesudah (pre-post) Hari I

\begin{tabular}{cccc}
\hline Kadar Gula Darah & N & Mean & $\begin{array}{l}\text { Standar } \\
\text { Deviasi }\end{array}$ \\
\hline Pre & 10 & 249,40 & 58,205 \\
Post & 10 & 217,80 & 67,260 \\
Valid N (listwise) & 10 & & \\
\hline
\end{tabular}

Sumber : Data Primer 2018

Dari tabel 6 diatas menunjukkan bahwa dari 10 jumlah responden yang valid, terdapat nilai ratarata kadar gula darah pre-post yaitu 249,40-217,80 $\mathrm{mm} / \mathrm{Hg}$, dan nilai standar deviasi pre-post yaitu 58,205-67,260.
Tabel 7

Distribusi Frekuensi Responden Menurut Kadar Gula Darah Sebelum Senam (Pre) Hari II

\begin{tabular}{ccc}
\hline Kadar Gula Darah & $\mathrm{N}$ & $\%$ \\
\hline $100-200 \mathrm{mg} / \mathrm{dL}$ & 1 & 10,0 \\
$201-300 \mathrm{mg} / \mathrm{dL}$ & 8 & 80,0 \\
$301-400 \mathrm{mg} / \mathrm{Dl}$ & 1 & 10,0 \\
\hline Total & 10 & 100,0 \\
\hline
\end{tabular}

Sumber : Data Primer 2018

Dari tabel 7 diatas menunjukkan bahwa dari 10 jumlah responden terdapat $1(10,0 \%)$ responden yang kadar gula darah 100-200 mg/dL, sebanyak 8 $(80,0 \%)$ responden yang kadar gula darah 201-300 $\mathrm{mg} / \mathrm{dL}$, dan sebanyak $1(10,0 \%)$ responden yang kadar gula darah $301-400 \mathrm{mg} / \mathrm{dL}$.

Tabel 8

Distribusi Frekuensi Responden Menurut Kadar Gula Darah Sesudah Senam (Post) Hari II

\begin{tabular}{ccc}
\hline Kadar Gula Darah & N & $\%$ \\
\hline Menurun & 9 & 90,0 \\
Tidak Menurun & 1 & 10,0 \\
\hline Total & 10 & 100,0 \\
\hline Sumber : Data Primer 2018 &
\end{tabular}

Dari tabel 8 diatas menunjukkan bahwa dari 10 jumlah responden terdapat $9(90,0 \%)$ responden yang kadar gula darah menurun, dan sebanyak $1(10,0 \%)$ responden yang kadar gula darah tidak menurun. hal ini disebabkan karena adanya faktor dari responden yang sering mengkonsumi makanan yang dapat meningkatkan kadar gula darah sehingga berdampak pada glukosa darah yang tidak mengalami perubahan walaupun sudah diberikan terapi senam diabetes.

Tabel 9

Distribusi Frekuensi Responden Menurut Kadar Gula Darah Sebelum dan sesudah (pre-post) Hari II

\begin{tabular}{cccc}
\hline $\begin{array}{c}\text { Kadar Gula } \\
\text { Darah }\end{array}$ & N & Mean & $\begin{array}{c}\text { Standar } \\
\text { Deviasi }\end{array}$ \\
\hline Pre & 10 & 248,50 & 49,049 \\
Post & 10 & 217,40 & 70,224 \\
Valid N & 10 & & \\
(listwise) & & & \\
\hline
\end{tabular}


Jurnal Media Keperawatan: Politeknik Kesehatan Makassar

Vol. 09. No.02. 2018

e-issn : 2622-0148, p-issn : 2087-0035

Sumber : Data Primer 2018

Dari tabel 9 diatas menunjukkan bahwa dari 10 jumlah responden yang valid, terdapat nilai rata-rata kadar gula darah pre-post yaitu 248,50$217,224 \mathrm{mg} / \mathrm{dL}$, dan nilai standar deviasi pre-post yaitu 49,049-70,224

Tabel 10

Distribusi Frekuensi Responden Menurut Kadar Gula Darah Sebelum Senam (Pre) Hari III

\begin{tabular}{ccc}
\hline Kadar Gula Darah & $\mathrm{N}$ & $\%$ \\
\hline $100-200 \mathrm{mg} / \mathrm{dL}$ & 3 & 30,0 \\
$201-300 \mathrm{mg} / \mathrm{dL}$ & 6 & 60,0 \\
$301-400 \mathrm{mg} / \mathrm{dL}$ & 1 & 10,0 \\
\hline Total & 10 & 100,0 \\
\hline
\end{tabular}

Sumber : Data Primer 2018

Dari tabel 10 diatas menunjukkan bahwa dari 10 jumlah responden terdapat $3 \quad(30,0 \%)$ responden yang kadar gula darah $100-200 \mathrm{mg} / \mathrm{dL}$, sebanyak $6(60,0 \%)$ responden yang kadar gula darah 201-300 mg/dL, dan sebanyak $1(10,0 \%)$ responden yang kadar gula darah $301-400 \mathrm{mg} / \mathrm{dL}$

Tabel 11

Distribusi Frekuensi Responden Menurut Kadar Gula Darah Sesudah Senam (Post) Hari III

\begin{tabular}{ccc}
\hline Kadar Gula Darah & N & $\%$ \\
\hline Menurun & 9 & 90,0 \\
Tidak Menurun & 1 & 10,0 \\
\hline Total & 10 & 100,0 \\
\hline
\end{tabular}

Sumber : Data Primer 2018

Dari tabel 11 diatas menunjukkan bahwa dari 10 jumlah responden terdapat $18(90,0 \%)$ responden yang kadar gula darah menurun, dan sebanyak $2(10,0 \%)$ responden yang kadar gula darah tidak menurun.hal ini disebabkan karena responden tidak mengikuti instruktur senam dengan benar sehinga tidak terjadi penurunan glukosa darah secera signifikan.
Tabel 12

Distribusi Frekuensi Responden Menurut Kadar Gula Darah Sebelum dan sesudah (pre-post) Hari III

\begin{tabular}{cccc}
\hline $\begin{array}{c}\text { Kadar Gula } \\
\text { Darah }\end{array}$ & N & Mean & $\begin{array}{c}\text { Standar } \\
\text { Deviasi }\end{array}$ \\
\hline Pre & 10 & 230,30 & 52,205 \\
Post & 10 & 212,50 & 64,660 \\
$\begin{array}{c}\text { Valid N } \\
\text { (listwise) }\end{array}$ & 10 & & \\
\hline Sumber : Data Primer 2018 &
\end{tabular}

Dari tabel 12 diatas menunjukkan bahwa dari 10 jumlah responden yang valid, terdapat nilai ratarata kadar gula darah pre-post yaitu 230,30-212,50 $\mathrm{mm} / \mathrm{Hg}$, dan nilai standar deviasi pre-post yaitu 52,205-64,660.

b. Minggu II

Tabel 13

Distribusi Frekuensi Responden Menurut Kadar Gula Darah Sebelum Senam (Pre) Hari I

\begin{tabular}{ccc}
\hline Kadar Gula Darah & $\mathrm{N}$ & $\%$ \\
\hline $100-200 \mathrm{mg} / \mathrm{dL}$ & 0 & 0,0 \\
$201-300 \mathrm{mg} / \mathrm{dL}$ & 10 & 100,0 \\
$301-400 \mathrm{mg} / \mathrm{dL}$ & 0 & 0,0 \\
\hline Total & 10 & 100,0 \\
\hline
\end{tabular}

Sumber : Data Primer 2018

Dari tabel 13 diatas menunjukkan bahwa dari 10 jumlah responden terdapat $0(0,0 \%)$ responden yang kadar gula darah 100-200 mg/dL, sebanyak $10(100,0 \%)$ responden yang kadar gula darah 201 $300 \mathrm{mg} / \mathrm{dL}$, dan sebanyak $0(0,0 \%)$ responden yang kadar gula darah $301-400 \mathrm{mg} / \mathrm{dL}$.

Tabel 14

Distribusi Frekuensi Responden Menurut Kadar Gula Darah Sesudah Senam (Post) Hari I

\begin{tabular}{ccc}
\hline Kadar Gula Darah & N & $\%$ \\
\hline Menurun & 9 & 90,0 \\
Tidak Menurun & 1 & 10,0 \\
\hline Total & 20 & 100,0 \\
\hline
\end{tabular}

Sumber : Data Primer 2018 
Vol. 09. No.02. 2018

e-issn : 2622-0148, p-issn : 2087-0035

Dari tabel 14 diatas menunjukkan bahwa dari 10 jumlah responden terdapat $9(90,0 \%)$ responden yang kadar gula darah menurun, dan sebanyak $1(10,0 \%)$ responden yang kadar gula darah tidak menurun. Hal ini disebabkan karena adanya faktor lain berupa kegemukan pada responden yang efeknya dapat menyebabkan terjadinya resitensi insulin, sehingga kadar gula darah responden susah diturunkan, walaupun sudah diberikan terapi senam diabetes.

Tabel 15

Distribusi Frekuensi Responden Menurut Kadar Gula Darah Sebelum dan sesudah (pre-post) Hari I

\begin{tabular}{cccc}
\hline $\begin{array}{c}\text { Kadar Gula } \\
\text { Darah }\end{array}$ & N & Mean & $\begin{array}{c}\text { Standar } \\
\text { Deviasi }\end{array}$ \\
\hline Pre & 10 & 251,40 & 28,250 \\
Post & 10 & 238,40 & 28,987 \\
$\begin{array}{l}\text { Valid N } \\
\text { (listwise) }\end{array}$ & 10 & & \\
\hline Sumber : Data Primer 2018 & &
\end{tabular}

Dari tabel 15 diatas menunjukkan bahwa dari 10 jumlah responden yang valid, terdapat nilai rata-rata kadar gula darah pre-post yaitu 251,40$238,40 \mathrm{mg} / \mathrm{dL}$, dan nilai standar deviasi pre-post yaitu $28,250-28,987$.

Tabel 16

Distribusi Frekuensi Responden Menurut Kadar Gula Darah Sebelum Senam (Pre) Hari II

\begin{tabular}{ccc}
\hline Kadar Gula Darah & $\mathrm{N}$ & $\%$ \\
\hline $100-200 \mathrm{mg} / \mathrm{dL}$ & 1 & 10,0 \\
$201-300 \mathrm{mg} / \mathrm{dL}$ & 8 & 80,0 \\
$301-400 \mathrm{mg} / \mathrm{Dl}$ & 1 & 10,0 \\
\hline Total & 10 & 100,0 \\
\hline
\end{tabular}

Sumber : Data Primer 2018

Dari tabel 16 diatas menunjukkan bahwa dari 10 jumlah responden terdapat $1(10,0 \%)$ responden yang kadar gula darah 100-200 mg/dL, sebanyak 8 $(80,0 \%)$ responden yang kadar gula darah $201-300$ $\mathrm{mg} / \mathrm{dL}$, dan sebanyak $1(10,0 \%)$ responden yang kadar gula darah $301-400 \mathrm{mg} / \mathrm{dL}$.
Tabel 17

Distribusi Frekuensi Responden Menurut Kadar Gula Darah Sesudah Senam (Post) Hari II

\begin{tabular}{ccc}
\hline Kadar Gula Darah & N & $\%$ \\
\hline Menurun & 9 & 90,0 \\
Tidak Menurun & 1 & 10,0 \\
\hline Total & 10 & 100,0 \\
\hline
\end{tabular}

Sumber : Data Primer 2018

Dari tabel 17 diatas menunjukkan bahwa dari 10 jumlah responden terdapat $9(90,0 \%)$ responden yang kadar gula darah menurun, dan sebanyak $1(10,0 \%)$ responden yang kadar gula darah tidak menurun.

hal ini disebabkan karena faktor usia yang dapat menghambat perubahan anatomi, fisiologi, yang dapat mempengaruhi kinerja insulin pada tubuh responden sehingga kadar gula darahnya susah mengalami penurunan.

Tabel 18

Distribusi Frekuensi Responden Menurut Kadar Gula Darah Sebelum dan sesudah (pre-post) Hari II

\begin{tabular}{cccc}
\hline $\begin{array}{c}\text { Kadar Gula } \\
\text { Darah }\end{array}$ & N & Mean & $\begin{array}{c}\text { Standar } \\
\text { Deviasi }\end{array}$ \\
\hline Pre & 10 & 248,90 & 34,054 \\
Post & 10 & 241,00 & 34,403 \\
Valid N & 10 & & \\
(listwise) & & & \\
\hline
\end{tabular}

Sumber : Data Primer 2018

Dari tabel 18 diatas menunjukkan bahwa dari 10 jumlah responden yang valid, terdapat nilai ratarata kadar gula darah pre-post yaitu $248,90 \mathrm{~mm} / \mathrm{Hg}$, dan nilai standar deviasi pre-post yaitu $34,054-$ 34,403 .

Tabel 19

Distribusi Frekuensi Responden Menurut Kadar Gula Darah Sebelum Senam (Pre) Hari III

\begin{tabular}{ccc}
\hline Kadar Gula Darah & N & $\%$ \\
\hline $100-200 \mathrm{mg} / \mathrm{dL}$ & 2 & 20,0 \\
$201-300 \mathrm{mg} / \mathrm{dL}$ & 7 & 70,0 \\
$301-400 \mathrm{mg} / \mathrm{dL}$ & 1 & 10,0 \\
\hline Total & 10 & 100,0 \\
\hline Sumber : Data Primer 2018
\end{tabular}


Jurnal Media Keperawatan: Politeknik Kesehatan Makassar

Vol. 09. No.02. 2018

e-issn : 2622-0148, p-issn : 2087-0035

Dari tabel 19 diatas menunjukkan bahwa dari 10 jumlah responden terdapat $2(20,0 \%)$ responden yang kadar gula darah 100-200 mg/dL, sebanyak 7 $(70,0 \%)$ responden yang kadar gula darah 201-300 $\mathrm{mg} / \mathrm{dL}$, dan sebanyak $1(10,0 \%)$ responden yang kadar gula darah $301-400 \mathrm{mg} / \mathrm{dL}$.

Tabel 20

Distribusi Frekuensi Responden Menurut Kadar Gula Darah Sesudah Senam (Post) Hari III

\begin{tabular}{ccc}
\hline Kadar Gula Darah & N & $\%$ \\
\hline Menurun & 8 & 90,0 \\
Tidak Menurun & 2 & 10,0 \\
\hline Total & 10 & 100,0 \\
\hline \multicolumn{2}{l}{ Sumber : Data Primer 2018 }
\end{tabular}

Dari tabel 20 diatas menunjukkan bahwa dari 10 jumlah responden terdapat $8(80,0 \%)$ responden yang kadar gula darah menurun, dan sebanyak $2(20,0 \%)$ responden yang kadar gula darah tidak menurun

- hal ini disebabkan karena responden kurang melakukan kepatuhan dalam penyuntikan insulin sehingga berdampak kepada kadar glukosa darahnya yang tidak mengalami perubahan sama sekali ketika sudah diberikan senam diabetes.

Tabel 21

Distribusi Frekuensi Responden Menurut Kadar Gula Darah Sebelum dan sesudah (pre-post) Hari III

\begin{tabular}{cccc}
\hline $\begin{array}{c}\text { Kadar Gula } \\
\text { Darah }\end{array}$ & N & Mean & $\begin{array}{c}\text { Standar } \\
\text { Deviasi }\end{array}$ \\
\hline Pre & 10 & 234,70 & 39,004 \\
Post & 10 & 225,20 & $35-990$ \\
Valid N & 10 & & \\
(listwise) & & & \\
\hline Sumber : Data Primer 2018 & & \\
Dari tabel 21 diatas menunjukkan bahwa dari \\
10 jumlah responden yang valid, terdapat nilai rata- \\
rata kadar gula darah pre-post yaitu 234,70-225,20 \\
mm/Hg, dan nilai standar deviasi pre-post yaitu \\
39,004-35,990.
\end{tabular}

2. Analisis Bivariat
a. Pengaruh Senam Diabetes terhadap Kadar Gula Darah Minggu I

Tabel 22

Pengaruh Senam Diabetes terhadap Kadar Gula

\begin{tabular}{|c|c|c|c|c|}
\hline \multicolumn{5}{|c|}{ Darah Hari I } \\
\hline $\begin{array}{l}\text { Kadar } \\
\text { Gula } \\
\text { Darah }\end{array}$ & Mean & $\begin{array}{l}\text { Standar } \\
\text { Deviasi }\end{array}$ & $P$ Value & $\mathrm{N}$ \\
\hline Pre & 1.9000 & 0,73786 & 014 & \\
\hline Post & 1.0000 & 0,00000 & & 10 \\
\hline $\begin{array}{l}\text { Sumber } \\
\text { nilai } p= \\
=0,05 \\
\text { senam } \\
\text { hari I. }\end{array}$ & $\begin{array}{l}\text { Data Prim } \\
\text { Berdasar } \\
\text {,014 yang } \\
\text { aka Ho dit } \\
\text { iabetes te }\end{array}$ & $\begin{array}{l}2018 \\
\text { hasil uji } \\
\text { tinya lebi } \\
\text { k yang be } \\
\text { dap kada }\end{array}$ & $\begin{array}{l}\text { oxon di pe } \\
\text { ecil dari } n \\
\text { i ada pen } \\
\text { ula darah }\end{array}$ & $\begin{array}{l}\text { roleh } \\
\text { lai a } \\
\text { aruh } \\
\text { pada }\end{array}$ \\
\hline
\end{tabular}

Tabel 23

Pengaruh Senam Diabetes terhadap Kadar Gula

\begin{tabular}{lcccc}
\multicolumn{5}{c}{ Darah Hari II } \\
\hline $\begin{array}{l}\text { Kadar } \\
\text { Gula } \\
\text { Darah }\end{array}$ & Mean & $\begin{array}{l}\text { Standar } \\
\text { Deviasi }\end{array}$ & $P$ Value & $\mathrm{N}$ \\
\hline Pre & 2.0000 & 0,47140 & 0,007 & 10 \\
Post & 1.1000 & 0,31623 & & 10 \\
\hline
\end{tabular}

Sumber : Data Primer 2018

Berdasarkan hasil uji Wilcoxon di peroleh nilai $p=0,007$ yang artinya lebih kecil dari nilai a $=0,05$ Maka Ho ditolak yang berarti ada pengaruh senam diabetes terhadap kadar gula darah pada hari ll.

Tabel 24

Pengaruh Senam Diabetes terhadap Kadar Gula Darah Hari III

\begin{tabular}{lcccc}
\hline $\begin{array}{l}\text { Kadar } \\
\text { Gula } \\
\text { Darah }\end{array}$ & Mean & $\begin{array}{l}\text { Standar } \\
\text { Deviasi }\end{array}$ & $P$ Value & N \\
\hline Pre & 1.8000 & 0,63246 & 0,035 & 10 \\
& & & 10 \\
\hline Post & 1.1000 & 0,31623 & & 10 \\
\hline \multicolumn{4}{l}{ Sumber : Data Primer 2018 }
\end{tabular}


Vol. 09. No.02. 2018

e-issn : 2622-0148, p-issn : 2087-0035

Berdasarkan hasil uji Wilcoxon di peroleh nilai $p=0,035$ yang artinya lebih kecil dari nilai $a$ $=0,05$ Maka Ho ditolak yang berarti ada pengaruh senam diabetes terhadap kadar gula darah pada hari III.

Hari I hasil penelitian menunjukan bahwa ada pengaruh senam diabetes terhadap penurunan kadar glukosa darah $(p=0,014)$. Hari II hasil penelitian menunjukan bahwa ada pengaruh senam diabetes terhadap penurunan kadar glukosa darah $(p=0,007)$. Hari III Hasil penelitian menunjukan bahwa ada pengaruh senam diabetes terhadap penurunan kadar glukosa darah $(p=0,035)$. Hasil penelitian ini sejalan dengan penelitian Graceistin Ruben (2016) hasil penelitian dengan judul pengaruh senam kaki diabetes terhadap perubahan kadar gula darah pada pasien diabetes mellitus tipe 2 di wilayah kerja Puskesmas Enamawira, hasil penelitian menunjukan ada pengaruh senam diabetes terhadap perubahan kadar gula darah pada pasien diabetes mellitus tipe 2 dengan nilai $p=0,000$.

Menurut teori Santoso, menunjukan bahwa senam diabetes adalah senam aerobic low implact dan ritmis dengan gerakan yang menyenangkan, tidak membosankan dan dapat di ikuti semua kelompok umur sehingga menarik antusiasme kelompok dalam klub-klub diabetes. Senam diabetes dapat meningkatkan kesegaran jasmani dan nilai aerobic yang optimal.

Menurut teori American Diabetes Association, (2006) mengatakan bahwa untuk mencapai hasil yang optimal, latihan jasmani dilakukan secara teratur 3-5 kali perminggu. Untuk pasien diabetes dengan kategori berat badan obesitas, penurunan berat badan dan glukosa darah akan mencapai maksimal jika latihan jasmani dilakukan lebih dari 5 kali perminggu. Latihan jasmani dilakukan sedikitnya 3 kali perminggu dengan tidak lebih dari 2 hari berurutan tanpa latihan jasmani. b. Pengaruh Senam Diabetes terhadap Kadar
Gula Darah Minggu II

Tabel 25

Pengaruh Senam Diabetes terhadap Kadar Gula Darah Hari I

\begin{tabular}{lcccc}
\hline $\begin{array}{l}\text { Kadar } \\
\text { Gula } \\
\text { Darah }\end{array}$ & Mean & $\begin{array}{l}\text { Standar } \\
\text { Deviasi }\end{array}$ & $P$ Value & N \\
\hline Pre & 2.0000 & 0,00000 & 0,003 & 10 \\
Post & 1.1000 & 0,31623 & & 10 \\
\hline
\end{tabular}

Sumber : Data Primer 2018

Berdasarkan hasil uji Wilcoxon di peroleh nilai $p=0,003$ yang artinya lebih kecil dari nilai $a$ $=0,05$ Maka Ho ditolak yang berarti ada pengaruh senam diabetes terhadap kadar gula darah pada hari I.

Tabel 26

Pengaruh Senam Diabetes terhadap Kadar Gula Darah Hari II

\begin{tabular}{lcccc}
\hline $\begin{array}{l}\text { Kadar } \\
\text { Gula } \\
\text { Darah }\end{array}$ & Mean & $\begin{array}{l}\text { Standar } \\
\text { Deviasi }\end{array}$ & $P$ Value & $\mathrm{N}$ \\
\hline Pre & 2.0000 & 0,47140 & 0,007 & 10 \\
Post & 1.1000 & 0,31623 & & 10 \\
\hline Sumber : Data Primer 2018 \\
\\
Berdasarkan hasil uji Wilcoxon di peroleh
\end{tabular}

nilai $p=0,007$ yang artinya lebih kecil dari nilai $a$ $=0,05$ Maka Ho ditolak yang berarti ada pengaruh senam diabetes terhadap kadar gula darah pada hari Il.

Tabel 27

Pengaruh Senam Diabetes terhadap Kadar Gula

\begin{tabular}{lcccc}
\multicolumn{5}{c}{ Darah Hari III } \\
\hline $\begin{array}{l}\text { Kadar } \\
\text { Gula } \\
\text { Darah }\end{array}$ & Mean & $\begin{array}{l}\text { Standar } \\
\text { Deviasi }\end{array}$ & P Value & $\mathrm{N}$ \\
\hline Pre & 1.9000 & 0,56765 & 0,020 & 10 \\
Post & 1.2000 & 0,42164 & & 10 \\
\hline
\end{tabular}

Sumber : Data Primer 2018

Berdasarkan hasil uji Wilcoxon di peroleh nilai $p=0,020$ yang artinya lebih kecil dari nilai $a=0,05$ Maka Ho ditolak yang berarti ada pengaruh senam diabetes terhadap kadar gula darah pada hari III. 
Hari I hasil penelitian menunjukan bahwa ada pengaruh senam diabetes terhadap penurunan kadar glukosa darah $(p=0,003)$. Hari II hasil penelitian menunjukan bahwa ada pengaruh senam diabetes terhadap penurunan kadar glukosa darah $(p=0,007)$. Hari III hasil penelitian menunjukan bahwa ada pengaruh senam diabetes terhadap penurunan kadar glukosa darah $(p=0,020)$. Hasil penelitian ini sejalan dengan penelitian Witriyani (2016) mengatakan bahwa diabetes mellitus dampak yang sangat berbahaya karena dapat menibulkan komplikasi. Oleh karena itu, diperlukan usaha pengendalian yang harus dilakukan oleh penderita diabetes mellitus dalam mengendalikan diabetes mellitus yang diperlukan empat pilar penyangga yang mendukung, yaitu edukasi, diet, obat dan olahraga. Banyak penderita diabetes mellitus yang lebih focus dan hanya mengutamakan pada penanganan diet, dam mengkomsumsi obatobatan. Hasil penlitian menunjukan bahwa ada pengaruh senam diabetes terhadap penurunan kadar glukosa darah dengan nilai $(p=0,001)$.

Menurut teori llyas dalam Darmayanti, (2015) dalam teorinya mengatakan bahwa kegiatan fisik dinamik yang melibatkan kelompok otot-otot utama akan meningkatkan ambilan oksigen sebesar 15-20 kali lipat karena peningkatan laju metabolic pada otot yang aktif. Ventilasi pulmoner dapat mencapai $100 \mathrm{~L} /$ menit dan curah jantung meningkat hingga 20-30 L/menit, untuk memenuhi kebutuhan otot yang aktif. Terjadi dilatasi arteriol maupun kapiler yang menyebabkan lebih banyak jala-jala kapiler terbuka sehingga reseptor insulin lebih banyak dan lebih aktif/lebih peka (Yunir dalam Damayanti, 2015). Kepekaan reseptor insulin berlangsung lama bahkan sampai latihan telah berakhir. Jaringan otot yang aktif/ peka insulin disebut jaringan non insulin dependent dan jaringan otot pada keadaan istirahat membutuhkan insulin untuk menyimpan glukosa, sehingga di sebut jaringan insulin dependent. Pada fase pemulihan post exercise terjadi pengisian kembali cadangan glikogen otot dan hepar. Aktivitas glikogenik berlangsung terus sampai 12-24 jam post exercise, menyebabkan glukosa darah kembali normal.
Menurut teori Damayanti (2015) mengatakan bahwa senam atau latihan jasmani utama dalam pengaturan kadar glukosa darah. Masalah utama pada diabetes mellitus tipe 2 adalah kurangnya respons reseptor terhadap insulin (resistensi insulin). Adanaya menyebabkan ganggua tersebut menyebabkan insulin tidak dapat membantu transfer glukosa kedalam sel. Permeabilitas membran meningkat pada otot yang berkontraksi, sehingga saat latihan jasmani atau senam resistensi insulin berkurang sementara sensitivitas insulin meningkat sehingga latihan jasmani atau senam yang teratur dapat memperbaiki pengaturan kadar glukosa darah dan sel.

Hasil penelitian ini peneliti berasumsi bahwa semakin baik dilakukan senam diabetes maka semakin baik tingkat penyembuhan penyakit diabtes yang ditandai dengan penurunan glukosa darah ketika selesai melakukan aktivitas berupa senam diabetes, hal ini dapat membuktikan bahwa senam kaki diabetes dapat mempengaruhi terjandinya penurunan glukosa darah, sehingga ketika pasien sering atau rutin melakukan senam tersebut akan berdampak efek terhadap penyembuhan penyakit diabetesnya.

\section{A. Kesimpulan}

Berdasarkan hasil penelitian yang telah dilakukan dapat disimpulkan bahwa :

1. Nilai rata-rata kadar gula darah responden sebelum dilakukan senam diabetes pada minggu I (Hari I : 249,40, Hari II : 248,50, Hari III : 230,30) dan Minggu II (Hari I : 251,40, Hari II : 248,90, Hari III : 234,70).

2. Nilai rata-rata kadar gula darah responden sesudah dilakukan senam diabetes pada minggu I (Hari I : 217,80, Hari II : 217,40, Hari III : 212,50) dan Minggu II (Hari I : 238,40, Hari II : 241,00, Hari III : 225,20).

3. Ada pengaruh senam diabetes terhadap kadar gula darah pada penderita diabetes tipe 2 di Puskesmas Antara Kota Makassar pada minggu I (Hari I $p=0,014$ ), (Hari II $p=0,007$ ), (Hari III $p=0,035$ ). Ada pengaruh senam 
Jurnal Media Keperawatan: Politeknik Kesehatan Makassar

Vol. 09. No.02. 2018

e-issn : 2622-0148, p-issn : 2087-0035

diabetes terhadap kadar gula darah pada penderita diabetes tipe 2 di Puskesmas Antara Kota Makassar pada minggu II (Hari I $p=0,003)$, (Hari II $p=0,007$ ), (Hari III $p=0,020$ ).

\section{B. Saran}

1. Dalam penelitian ini memberi masukan kepada institusi Puskesmas Antara Kota Makassar bahwa pelaksanaan senam dapat menurunkan kadar gula darah agar sekiranya selalu memberikan prosedur serta pemahaman senam diabetes setiap hari untuk penderita diabetes sehingga pasien mampu melakukannya dengan baik yang efeknya dapat membantu penyembuhkan penyakitnya.

2. Diharapkan bagi pelayanan kesehatan agar dapat menjadi motivator dan memberikan penyuluhan yang intensif bagi penderita diabetes melitus untuk melakukan senam diabetes rutin demi menurunkan kadar gula darah dan mencegah komplikasi diabetes melitus.

\section{DAFTAR PUSTAKA}

Bilous, R., \& Donelly, R. (2014). Buku Pegangan Diabetes. Jakarta: Bumi Medika.

Nuari, N. A. (2017). Strategi Manajemen Edukasi Pasien Diabetes Mellitus. Yogyakarta: Deepublish.

Nugraha, A., Kusnadi, E., \& Subagja, S. (2016). Kadar Gula Darah Sebelum dan Sesudah Melaksanakan Senam Diabetes pada Pasien Diabetes Meitus Tipe II. Jurnal IImiah Kesehatan .

Salindeho, A., Mulyadi, \& Rottie, J. (2016). Pengaruh Senam Diabetes Melitus Terhadap Kadar Gula Darah Penderita Diabetes Melitus Tipe 2 Di Sanggar Senam Persadia. ejournal Keperawatan , 4, 2.

Witriyani. (2016). Efektifitas Senam Diabetes Melitus Dalam Menurunkan Kadar Gula Darah Pada Penderita Diabetes Melitus Di Wilayah Kerja Puskesmas Kayumas.

Damayanti, S. (2015). Diabetes Mellitus \& Penatalaksanaan Keperawatan. Yogyakarta: Nuha Medika.

Wijaya, A. S., \& Putri, Y. M. (2013). KMB 2 Keperawatan Medikal Bedah (Keperawatan Dewasa). Yogyakarta: Nuha Medika.

Setiadi. (2013). Konsep dan Praktik Penulisan Riset Keperawatan . Yogyakarta: Graha IImu.

Notoatmodjo, S. (2015). Metodologi Penelitian Kesehatan. Jakarta: Rineka Cipta.

Hidayat, R. (2016). Pengaruh Senam Terhadap Kadar Gula Darah Pada Penderita Diabetes Mellitus Tipe 2 Di RSUD Puri Husada Tembilahan .

Maghfuri, A. (2016). Buku Pintar Perawatan Diabetes Mellitus. Jakarta: Salemba Medika.

Sari, R. N. (2012). Diabetes Mellitus. Yogyakarta: Nuha Medika.

Yendi, \& Adwiyana. (2014). Pengaruh Latihan Jasmani Senam Diabetes Mellitus Terhadap Penurunan Kadar Gula Darah Penderita Diabetes Mellitus Di Wilayah Kerja Puskesmas Rasimah Ahmad Kota Bukit Tinggi Tahun 2014. 
Jurnal Media Keperawatan: Politeknik Kesehatan Makassar

Vol. 09. No.02. 2018

e-issn : 2622-0148, p-issn : 2087-0035

Saryono, \& Anggraeni, M. D. (2017). Metodologi Penelitian Kualitatif dan Kuantitatif Dalam Bidang Kesehatan. Yogyakarta: Nuha Medika.

Soegondo, S., Soewondo, P., \& Subekti, I. (2015). Penatalaksanaan Diabetes Mellitus Terpadu. Jakarta: Badan Penerbit FKUI.

IDF.(2017).New IDF figures show continued increase in diabetes across the globe, reiterating the need for urgent action. https://www.idf.org/news/94:new-idf-figures-show-continued-increase-in-diabetes-across-theglobe,-reiterating-the-need-for-urgent-action.html. Diaksestanggal 30 Januari 2018

Tarwoto.(2016).Keperawatan Medikal Bedah Sistem Endokrin. Jakarta : Trans Info Media. 